\title{
APPLICATION OF A PROPOSED TLS MODEL IN A LEAN
} PRODUCTIVE SYSTEM

\author{
Rui M.F.Dias \\ A\&l, Portugal \\ rdias1263@hotmail.com \\ Luis Diogo Silva \\ UNIDEMI,FCT,UNL, Portugal \\ Id.silva@campus.fct.unl.pt \\ Alexandra Tenera \\ UNIDEMI,FCT,UNL, Portugal \\ abt@fct.unl.pt
}

Submission: $23 / 04 / 2018$

Revision: 08/05/2018

Accept: 25/07/2018

\section{ABSTRACT}

The current market, becoming more rigid, forces companies to search continuously for innovation and improvement of their processes and products as a way to keep competitive and gain strategic advantages. Due to the global economic crisis, more and more companies try an approach through new management methodologies that allow better performances in terms of earning, profit and cost reduction. The present article proposes an integrated TOC (Theory of Constraints), Lean and Six-Sigma (TLS) model, with the objective of improving continuously a productive system, although it shows flexibility to be applied in other kinds of systems. The model synergistically integrate the best practices found in existing TOC, Lean and Six-Sigma models. The proposed model derivatives mainly from Eliyahu Goldratt's TOC model of the " 5 focus steps" and TLS model "Ultimate Improvement Cycle", developed by Bob Sproull. The proposed TLS model was tested on an important Portuguese Manufacture. The implementation of a first continuous improvement cycle was completed and a second cycle began. The main results obtained by the implementation of the TLS model were extremely satisfactory. 
Keywords: Continuous Improvement; TOC; Lean; Six-Sigma; TLS

\section{INTRODUCTION}

The XX century was of extreme importance to the industrial world where three big production paradigms arised and which are still decisive in the way managers administer industrial plants and their processes till nowadays (JACOBS; CHASE; AQUILANO, 2009).

From those new paradigms, came some new methodologies that through continuous improvement cycles can create satisfactory results on productive system's performances. Current studies prove that the most effective continuous improvement systems in terms of costs reduction are gaining market share and improving quality currently are the models that combines the Theory of Constraints, Lean and Six-Sigma methodologies (PIRASTEH; FARAH, 2006; SPROULL, 2009).

Those models are known as TLS models.

On this paper, one TLS model is presented and the results of the proposed model tested in a real Lean productive system are shown. The model was built after reviewing each methodology by itself and the TLS existing models. Then, the three main classic improvement methodologies were compared and the converging characteristics were analysed, in order to make them merge synergistically.

A brief exploitation was made of the existing integrative TLS models and the best practises found on each model were resorted to be able to build a logic model. The main objective of creating a continuous improvement model was to improve an existing Lean productive system of an important Portuguese manufacturer.

The best state of the art found during the review of the models, which integrate the Theory of Constraint, Lean and Six Sigma, use TOC to focus and identify system constraints and some Lean and Six Sigma (LSS) tools which are mainly utilized to eliminate waste and reduce variability in the constraint step.

\section{BRIEF THEORETICAL REVIEW ON CONTINUOUS IMPROVEMENT SYSTEMS}

The biggest goal of continuous improvement systems is to concretize all the objectives defined by an organization in a systematic, consistent and gradual way (PEREIRA; REQUEIJO, 2012). 


\subsection{Theory of Constraints}

TOC was developed firstly as an Optimized Production Timetables scheduling software in 1979 and five years latter its model was conceptualized on the bestseller "The Goal" by Goldratt and Cox (GOLDRATT; COX, 2004). The basic concept of TOC is often introduced through the chain analogy, where the chain is only as strong as its weakest link. So, any improvement that does not improve the performance of the weakest link most likely will not improve the system and can be considered waste (DAVIES; MABIN, 2009).

TOC is more than a system to find constraints; TOC is a continuous improvement system to improve and manage the system constraint performance in the global context, trying to achieve overall system improvement and not just localized improvements. TOC is a system focus, first on the system's leverage points (constraints) and then on how all parts of the system that impact on the operation of the leverage points.

Constraints could be physical if the issue is related to equipment, materials or resources or politics if caused by the market, policy of management, roles, standards or measures (LUCAS; TENERA, 2014).

The TOC evolved from the production planning technology to a system of managing tools that integrates the areas of logistics, production, project management, finances, accounting, performance measurement, distribution and supply chain, marketing, sales and problem resolution (COX; SCHLEIER, 2010).

The TOC as a methodology of continuous improvement uses a set of tools that aim to promote and elevate the performance of the systems, grouped in Table 1 in four main quadrants: 
Table 1: Schematic Synthesis of TOC

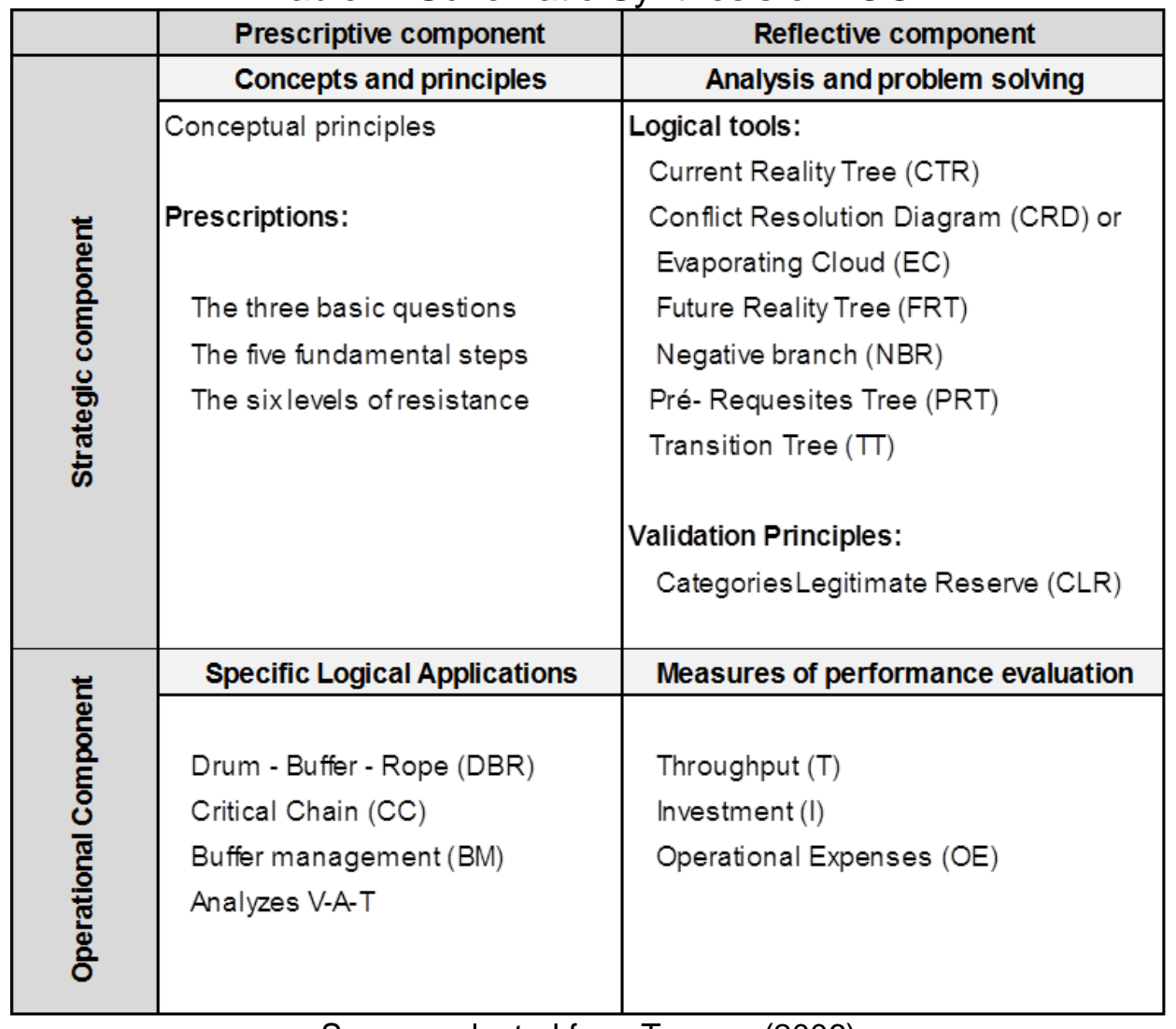

Source: adapted from Tenera, (2006)

- First quadrant - concepts and principles that define the strategic and prescriptive component of TOC;

- Second quadrant - analysis and problem solving tools;

- Third quadrant - operational and prescriptive where logical applications are proposed to apply to certain specific systems;

- Fourth quadrant - performance evaluation measures.

In the model presented in this paper we use two different tools of TOC methodology

- $\quad$ Five Focusing Steps - Figure 1

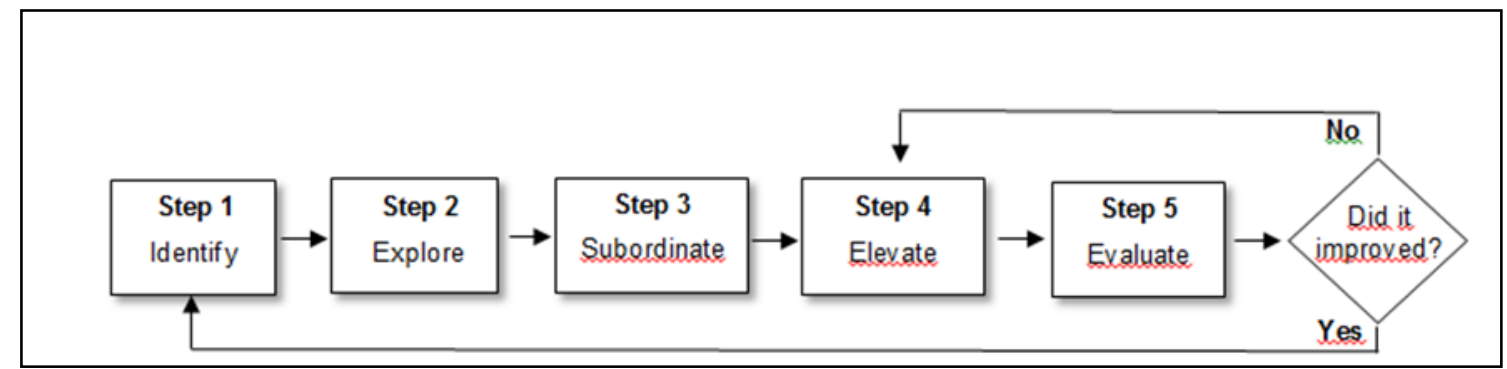

Figure 1: Goldratt's five focus steps model 
The five steps can be briefly described as (TENERA, 2006; PRETORIUS, 2014).

a) Identify the system's constraint - It's identified which process or processes limit all system's performance;

b) Decide how to exploit the constraint - It should be answered to the question: "How to make the constraint the most efficient possible? At this moment it's not resourced to financial investments and the constraint should be "squeezed" at his full potential.

c) Subordinate everything else to the above decision - This step insurances that all the other as processes work in order to support the constraint even if through losing some of its own capacity. The recommended tool to be applied on this step is DBR.

d) Elevate the system's constraint - The constraint's performance is potentiated. One way to improve is by investing in new resources.

e) Evaluate constraint - It's verified in this step if the capacity of the constraint is now superior to demand this means if the constrain has been broken. In that case the improvement cycle closes and returns to step 1 but can't allow inertia to become the new system constraint. Otherwise returns to step 4 and elevates the capacity until the process is no longer the constraint.

- Drum - Buffer- Rope (DBR) - Figure 2

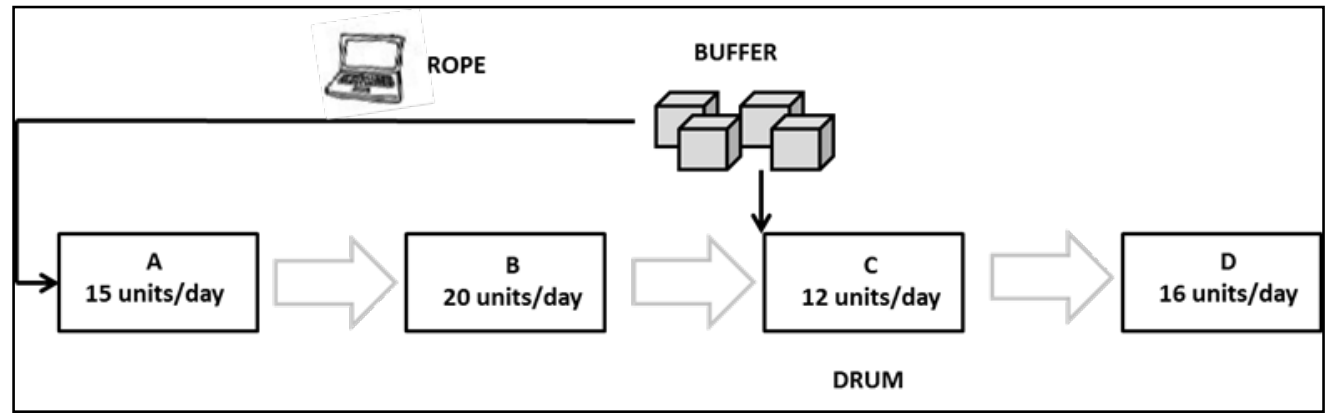

Figure 2: Drum-Buffer-Rope

Source: adapted from Tenera, (2006)

DBR promotes the constitution of strategic reserves (Buffer) in order to protect the Constraint (Drum) and the synchronization of the flow through logistic mechanisms of alert (Rope).

DBR is a hybrid method of programming production, where the materials and components are pushed into the production system through a system of communication called rope, which aims to guarantee the supply of the buffer that 
allows the fluctuations that can occur in the productive flow do not affect the performance of the constraint, drum. (Tenera, 2006)

\subsection{Lean Production}

Lean appeared in the middle of $X X$ century in Toyota associated with the bigger complexity of processes. It covers since the conception and develop of products, supply of materials, tools and components, productive processes until the commercialization of products.

The emphasis of this methodology is given to the optimization of processes, seek or elimination of non-value activities and on generation of value to stakeholders (PIRASTEH; FOX, 2010).

According to Womack and Jones there are 5 principles that define Lean (WOMACK; JONES, 1996):

a) Define Value from the perspective of the final costumer;

b) Identify the completed chain of value for each product or family of products and eliminate waste;

c) Take actions that make flow the activities that generate value;

d) Pull production to clients demand, this mean provide what the customer wants, when he wants;

e) Pursue perfection.

Identification and elimination of waste is the most fundamental aspect to an organization that implements Lean. In Toyota's production system, Shigeo Shingo identifies 7 Muda that correspond to the biggest wastes that don't add value to the costumer, as show and described on Table 2 (PACHECO, 2014):

Table 2: Identification and description of the 7 Muda

\begin{tabular}{|c|c|c|}
\hline Muda & Description & $\begin{array}{c}\text { Recommended } \\
\text { Lean Tools }\end{array}$ \\
\hline Overproduction & $\begin{array}{c}\text { Producing something when it's not needed. } \\
\text { Results in excess of inventory, resources, energy } \\
\text { and materials utilization. Generates loss of } \\
\text { planning flexibility. }\end{array}$ & $\begin{array}{c}\text { - Takt Time } \\
\text { - Kanban } \\
\text { - SMED }\end{array}$ \\
\hline Defects & $\begin{array}{c}\text { Production that needs reprocessing or being } \\
\text { eliminated. It's caused by lack of quality, low } \\
\text { performance or human failures. Causes } \\
\text { productivity decrease. }\end{array}$ & $\begin{array}{c}\text { - Jidoka } \\
\text { - Poka-Yoke }\end{array}$ \\
\hline $\begin{array}{c}\text { Unnecessary } \\
\text { inventory }\end{array}$ & $\begin{array}{c}\text { Having a quantity of inventory superior to the } \\
\text { immediate needs, causes the unnecessary costs } \\
\text { of material possession and lower costumer's } \\
\text { service rate. }\end{array}$ & $\begin{array}{c}\text { - Just-in-time } \\
\text { - Heijunka }\end{array}$ \\
\hline $\begin{array}{c}\text { Inappropriate } \\
\text { processing }\end{array}$ & $\begin{array}{c}\text { Results in incompatibilities between the necessary } \\
\text { processes and tools to make a product. }\end{array}$ & $\begin{array}{c}\text { - Pull system } \\
\text { praizen }\end{array}$ \\
\hline
\end{tabular}


DOI: 10.14807/ijmp.v10i1.830

\begin{tabular}{|c|c|c|}
\hline $\begin{array}{c}\text { Excessive } \\
\text { transportation }\end{array}$ & $\begin{array}{c}\text { Can be reduced by layout changing, } \\
\text { transportation system or alteration to a production } \\
\text { cell. }\end{array}$ & $\begin{array}{c}\text { - VSM } \\
\text { - Continuous flow }\end{array}$ \\
\hline Waiting & $\begin{array}{c}\text { Inactivity for a long period due to operators and } \\
\text { material and lack of information can result in a } \\
\text { poor flow and increasing of Lead Time. }\end{array}$ & $\begin{array}{c}\text { - Standard Work } \\
\text { - Heijunka } \\
\text {-SMED }\end{array}$ \\
\hline $\begin{array}{c}\text { Unnecessary } \\
\text { motion }\end{array}$ & $\begin{array}{c}\text { Bad organization of workplaces due to weak } \\
\text { ergonomics, lack of formation or demotivation of } \\
\text { operators and inappropriate layout. }\end{array}$ & $\begin{array}{c}-5 \mathrm{~S} \\
\text {-VSM }\end{array}$ \\
\hline
\end{tabular}

\subsection{Six-Sigma}

Six-Sigma was developed initial by Motorola executives in the late 1980s then some years later, it was exploited and developed by General Electric, Honeywell and others companies (TENNANT, 2001).

Six-Sigma is defined as a "business strategy used to improve business profitability, to improve the effectiveness and efficiency of all operations to meet or exceed customer's needs and expectations".

Applied for the first time in manufacturing operations, it rapidly expanded to different functional areas such as marketing, engineering, procurement, services, and administrative support, as organizations perceived its benefits, especially when they associated financial returns and cost reduction with implementation of Six Sigma (PACHECO, 2014).

The methodology statistic basis is to try to optimize processes until an efficiency rate of $99,99966 \%$, where a process must not produce more than 3.4 defects per million opportunities.

The Greek letter $\sigma$ (Sigma) correspond to a standard deviation of process variability so in Six-Sigma it is intended that all processes own a variability inferior to six standard deviation compared to the average of the process.

The most common improvement cycle used to apply Six-Sigma is the DMAIC cycle as shown at Figure 3. Each phase of the cycle and the recommended tools to apply in every of the five phases are shown at Table 3 (KHANDEKAR; SULAKHE, 2014): 


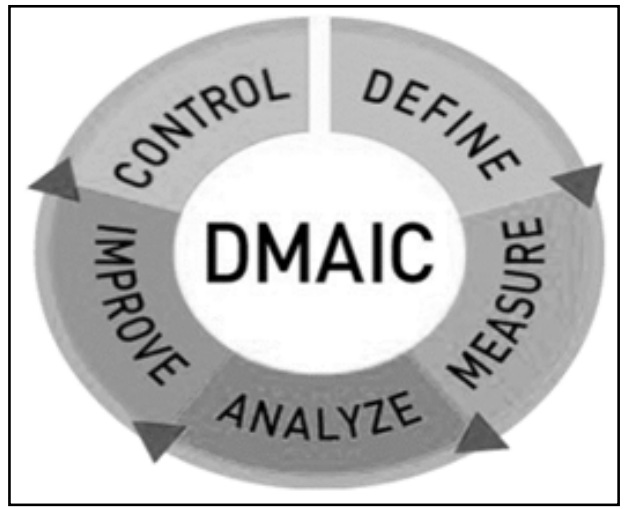

Figure 3: DMAIC cycle

Table 3: DMAIC cycle phases, description and tools used

\begin{tabular}{|c|c|c|}
\hline Phase & Description & $\begin{array}{l}\text { Recommended Six- } \\
\text { Sigma Tools }\end{array}$ \\
\hline Define & $\begin{array}{l}\text { Define with precision the project where are identified } \\
\text { the objectives and the scope. It is chosen a team } \\
\text { and decided the timeline. It's important to define the } \\
\text { priorities of the client in matters of what he considers } \\
\text { to have most impact on quality. }\end{array}$ & $\begin{array}{l}\text { - Project Charter } \\
\text { - VOC (Voice of } \\
\text { Client) } \\
\text {-Run Chart and } \\
\text { Flowchart }\end{array}$ \\
\hline Measure & $\begin{array}{l}\text { Define the baseline of the project, so the location or } \\
\text { focus of the problem. It is defined the metrics to } \\
\text { evaluate and the criteria of rejection in the inspection } \\
\text { method. Data of the system is collected and } \\
\text { analysed. }\end{array}$ & $\begin{array}{l}\text { - Pareto chart } \\
\text { - Control chart } \\
\text { - Gage R\&R study }\end{array}$ \\
\hline Analyse & $\begin{array}{l}\text { For the main problems that cause variability in the } \\
\text { processes, the critical factors and the root causes } \\
\text { that are the origin of the variability are identified. It is } \\
\text { searched the tools that are able to continuously } \\
\text { improve the process more easily. }\end{array}$ & $\begin{array}{l}\text { - Ishikawa diagram } \\
\text { - DOE (Design of } \\
\text { Experiences) } \\
\text { - FMEA Matrix } \\
\text { - ANOVA }\end{array}$ \\
\hline Improve & $\begin{array}{c}\text { It's proposed, evaluated and implemented solutions } \\
\text { to each problem found in a way to eliminate defects } \\
\text { and improve the process respecting the needs of the } \\
\text { client. }\end{array}$ & $\begin{array}{l}\text { - Brainstorming } \\
\text { - Opportunities } \\
\text { Flowchart } \\
\text { - } 5 \text { Whys }\end{array}$ \\
\hline Control & $\begin{array}{l}\text { Ensure that the solutions are reached with success } \\
\text { and maintain sustained at long term. The } \\
\text { improvements should but standardized and the } \\
\text { statistic control of processes must be implemented. }\end{array}$ & $\begin{array}{l}\text { - Control Charts } \\
\text { - Hypothesis Tests } \\
\text { - Audits }\end{array}$ \\
\hline
\end{tabular}

\subsection{Integration of Theory of Constraints, Lean and Six Sigma}

All continuous improvement methodology brings competitive advantages by itself for any company's system.

The importance of the three philosophies, up until now described, the gains and successes obtained with them, created in the users and researchers the necessity to evaluate if the complementarity between the methodologies may fill the individual weaknesses of each one and improve the system performance. 
These investigations, more than evaluating convergences and complementarities, have essentially sought to integrate the three methodologies, and creating more consistent models that promote the continuous improvement of organizations.

Controlled experiences on real industrial plants demonstrate that is possible to obtain more considerable improvements when combining TOC five focus step model with Lean and Six-Sigma, compared with applying each methodology isolated (PIRASTEH; FARAH, 2006).

It's possibly to increase the market share and without spending money due to the benefits that Lean and Six-Sigma can bring integrated with the Theory of Constraints (SPROULL, 2009). In a study proposed by Piratesh \& Farah during two and half years in 21 industrial plants, the ones that applied TLS methodology obtained 4 times more profit than the plants that applied Lean or Six-Sigma alone and the people involved in the implementation of TLS projects showed more proud of the results obtain by the implementation (PIRASTEH; FOX, 2010), Figure 4 shows the results in terms of contribution for cost reduction in each methodology:

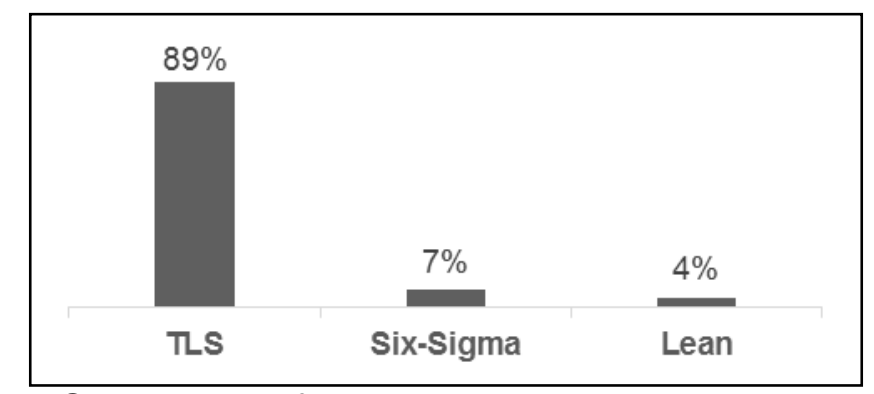

Figure 4: Contribution for cost reduction in each methodology Source: adapted from Pirasteh and Fox (2010)

The three main methodologies of improving systems continuously present different methods to improve the productive process of the organizations. In Table 4 is compared the main aspects encountered on each one: 
INDEPENDENT JOURNAL OF MANAGEMENT \& PRODUCTION (IJM\&P)

http://www.ijmp.jor.br

v. 10, n. 1, January - Ferbuary 2019

ISSN: 2236-269X

DOI: 10.14807/ijmp.v10i1.830

Table 4: Six Sigma, Lean and TOC comparative results ((Sproull, 2010), (Stamm,

Neitzert, Singh, 2009), (AGI, 2009), (Pirasteh, Farah, 2006))

\begin{tabular}{|c|c|c|c|}
\hline Program & Six Sigma & Lean Maufacturing & Theory of Constraints \\
\hline Theory & Reduce variation & Remove Waste & Manage Constraints \\
\hline Origen & $\begin{array}{l}\text { Smith } \\
\text { Motorola and General Electric }\end{array}$ & $\begin{array}{l}\text { Toyota (Toyoda, Ohno and Shingo) } \\
\text { and NUMMl (Womack and Jones) }\end{array}$ & Goldratt \\
\hline Aplication Guidelines & $\begin{array}{l}\text { 1. Define } \\
\text { 2. Measure } \\
\text { 3. Analyze } \\
\text { 4. Improve } \\
\text { 5. Control }\end{array}$ & $\begin{array}{l}\text { 1. Identify alue } \\
\text { 2.Identify value stream } \\
\text { 3. Flow } \\
\text { 4.Pull } \\
\text { 5.Perfection }\end{array}$ & $\begin{array}{l}\text { 1. Identify constraints } \\
\text { 2. Exploit constraints } \\
\text { 3.Subordinate processes } \\
\text { 4. Elevate constraints } \\
\text { 5. Repeat cycle }\end{array}$ \\
\hline Focus & Problem focused - Redution of variation & $\begin{array}{c}\text { Flow focused - value (material and } \\
\text { information) }\end{array}$ & Systems constraints \\
\hline Assumptions & $\begin{array}{l}\text { A problem exists } \\
\text { Figures and numbers are valued } \\
\text { System output improves if variation } \\
\text { in all processes is reduced }\end{array}$ & $\begin{array}{l}\text { Waste removal will improve } \\
\text { business performance } \\
\text { Many small improvements are } \\
\text { better than systems analyses }\end{array}$ & $\begin{array}{l}\text { Emphasis on Speed and } \\
\text { volume } \\
\text { Uses existenting systems. } \\
\text { Process interdependence } \\
\end{array}$ \\
\hline Primary effect & Uniforn process output & Reduce flow time & Fast Througput \\
\hline Criticism & $\begin{array}{l}\text { System interation not considered } \\
\text { Process improved independently }\end{array}$ & $\begin{array}{l}\text { Satatiscal or system analysis } \\
\text { not valuated }\end{array}$ & $\begin{array}{l}\text { Minimal worker imput } \\
\text { Data analysis not valued }\end{array}$ \\
\hline Finantial Impact & Reducing operating costs & $\begin{array}{c}\text { Reducing inventory and } \\
\text { operating costs }\end{array}$ & Improve Througput \\
\hline $\begin{array}{l}\text { Distinguishing and value adding } \\
\text { contribution }\end{array}$ & $\begin{array}{l}\text { Organizational struture with } \\
\text { improvement experts(black belt and } \\
\text { grean belt), project oriented, } \\
\text { quantification of cost saving }\end{array}$ & $\begin{array}{c}\text { Pull, takt time, heijunka, one } \\
\text { piece flow, value stream mapping, } \\
\text { respect for people }\end{array}$ & Focus mechanism on constraints \\
\hline Implementation & Medium difficulty & Less difficulty & Major dificulty \\
\hline Aspects of the process & $\begin{array}{l}\text { Accurate statistics tolls. Specific } \\
\text { terminology. Specific experts estruture }\end{array}$ & $\begin{array}{l}\text { Management of the workflow by } \\
\text { JIT. Optimization }\end{array}$ & $\begin{array}{l}\text { Specific metric accounting. Systematic } \\
\text { focus on constraints }\end{array}$ \\
\hline Lot sizes & Does not mention & Small batches in the whole system & $\begin{array}{l}\text { Larger lots for contraints and smaller for } \\
\text { no bottlenecks }\end{array}$ \\
\hline Control of production & Does not mention & $\begin{array}{l}\text { Kanban triggers the release of } \\
\text { product }\end{array}$ & $\begin{array}{l}\text { The Drum-buffer-rope methodology is } \\
\text { used to release materials }\end{array}$ \\
\hline Production planning & Does not mention & $\begin{array}{l}\text { Detailed planning of the final } \\
\text { output. The other operations are }\end{array}$ & $\begin{array}{l}\text { Detailed planning for the restriction and } \\
\text { less detailed for no bottlenecks }\end{array}$ \\
\hline
\end{tabular}

The complementarities found in each methodology can be synthetized as (PACHECO, 2014; OKIMURA; SOUZA, 2012):

- Lean focus on flow aiming the waste losses and adding value to customer.

The application of value flow mapping and problem resolution tools, with the involvement of every hierarchical level, facilitates the cultural change to the continuous improvement of the production systems.

- Six-Sigma focus on the problem that aims the variability and defects reduction originating more stable and predictable processes. Due to his structured and disciplinary statistical tools, to solve complex problems it leads to big improvements in the quality of processes and in the design of new products. 
- TOC supports in the identification of system's constraints which should be the focus of all improvements actions made through Lean and Six-Sigma. Managing the constraint allows reduction of inventory besides the systematic improvements. Owning to an accounting system of gains it is possible to have an appropriated way of measuring the improvements through performance measures (Gain, Inventory and Operational cost).

\subsection{Brief exploration of the main existing TLS models}

The existing models have proved to be generic regarding to the destiny where they can be applied. Although the focus of some models being on productive systems, they can be adapted to be implemented on project management or on services.

The most relevant models found are: Bob Sproull's Ultimate Improvement Cycle (UCI) (SPROULL, 2010), iTLS model introduced by Pirasteh \& Farah in 2006 and revised in 2010 book "Profitability with no boundaries" by Pirateh \& Fox (PIRASTEH; FOX, 2010); TOCLSS model introduced by AGI and later developed in the book VELOCITY (AGI, 2009) and "Excelência 360" model developed by Eduardo Moura (MOURA, 2010).

The first two models previously presented were the most used as basis in the construction of the proposed model in this paper and for that reason they are presented with more detail.

The iTLS model uses the characteristics of TOC, to identify the constraint and focus the improvement there to the optimization of the global system, elevate the constraint and increase gains using the tools of Lean and Six-Sigma in a way to eliminate waste and variability. It's a continuous improvement model because it works like a cycle, so after applying the efforts to eliminate the first constraint, return to the begin to identify a new constraint and continue a cycle. Figure 5 shows the 7 steps existing in the models and the recommended tools and logics to be applied on each step. 


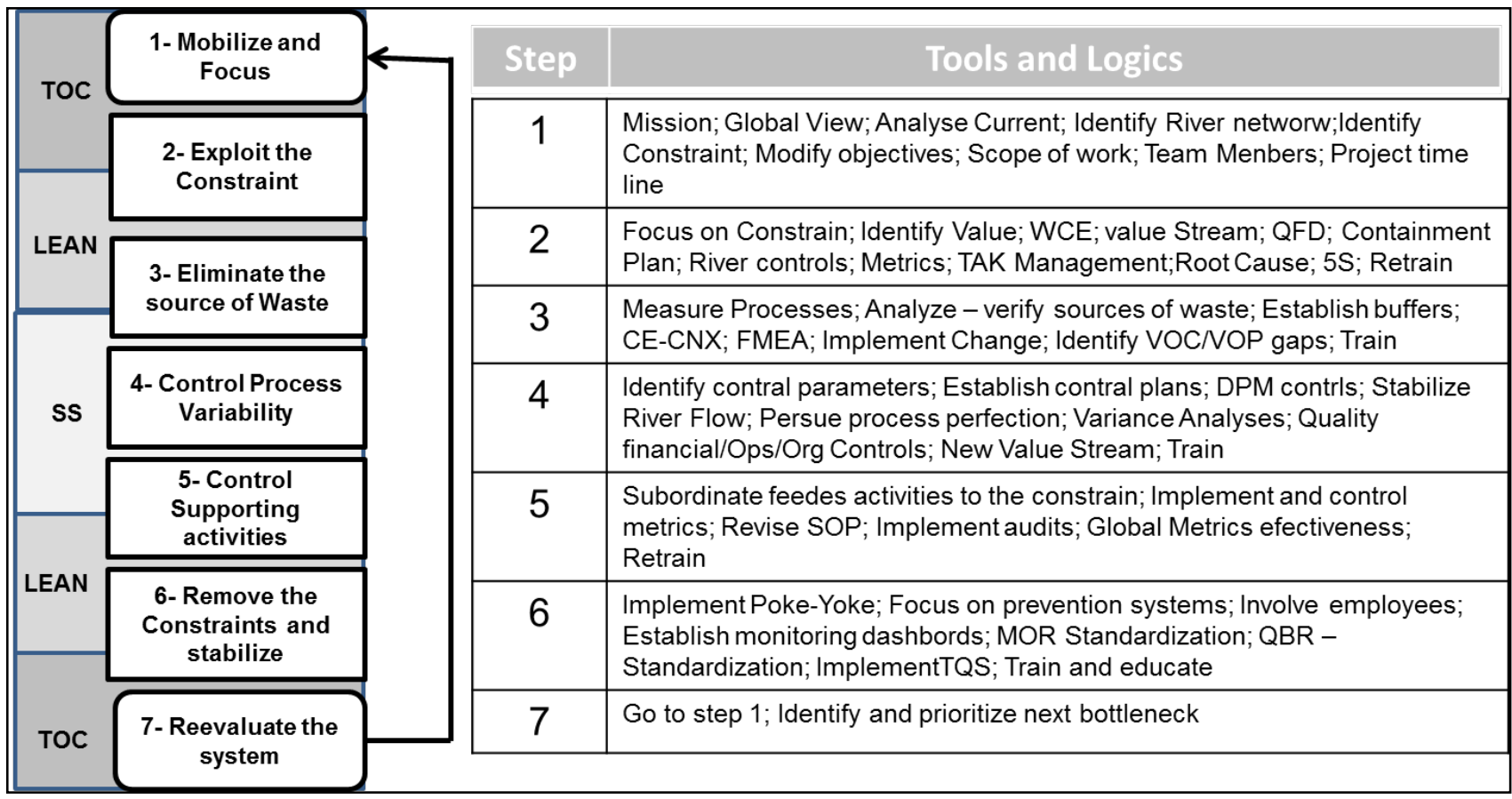

Figure 5: 7 Steps of iTLS model

Source: adapted from Pirasteh and Fox (2010)

a. Mobilize and focus - The stakeholders should get involved and the communication needs to be open from the beginning between key-people involved. Efforts are made to find the constraint with TOC tools and the root-cause must be analysed. It's decided where and how the efforts and which should be the expected returns.

b. Exploit the constraint - Value Stream Mapping Lean tools and new performance indicators are applied at this step.

c. Eliminate sources of waste - After being identified the value, Lean tools are implemented to eliminate waste, increase gains, reduce inventory and operational costs.

d. Control process variability - on this step Six-Sigma tools are applied to reduce the variability in critical processes. It's important to control process variability through statistical tools.

e. Control supporting activities - standards and mechanisms are established to keep critical processes under control. The processes that feed the constraint must be subordinated to avoid failures in supply the constraint process.

f. Remove the constraint and stabilize - ensure the correct application of the tools to remove the constraint and stabilize the process. 
INDEPENDENT JOURNAL OF MANAGEMENT \& PRODUCTION (IJM\&P)

http://www.ijmp.jor.br

v. 10, n. 1, January - Ferbuary 2019

ISSN: 2236-269X

DOI: 10.14807/ijmp.v10i1.830

The key to keep the process stable and controlled must lie on the formation of employees. It's necessary to ensure that performance indicators are fulfilled.

g. Revaluate the system - checking if the objectives initially defined were performed and if there is a new constraint. The final situation is compared with the initial one in terms of the appropriate indicators of performance.

Ultimate Improvement cycle combines harmonically the best practices in each of the three main continuous improvement cycles. This integration of TOC, Lean and Six-Sigma generates a powerful and rentable strategy for improving any system. On Figure 6, it's presented the model and although appearing complex, it's easy to interpret and follow:

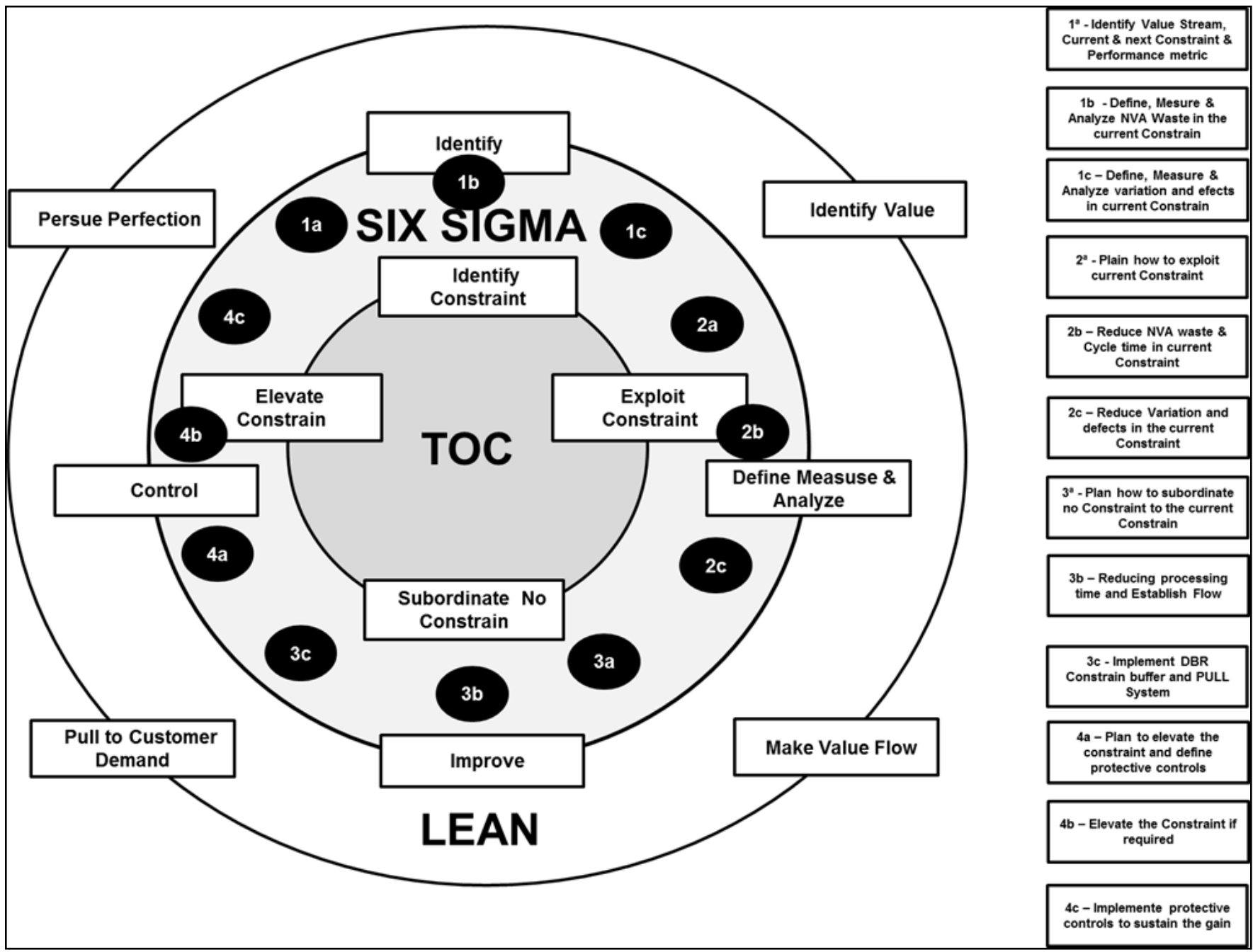

Figure 6: Ultimate Improvement Cycle model Source: Adapted from Sproull (2009)

The model is focused on Goldratt's 5 focus step model, in the 5 principles of Lean and in the 5 steps of DMAIC cycle that conciliate together a continuous 
INDEPENDENT JOURNAL OF MANAGEMENT \& PRODUCTION (IJM\&P)

http://www.ijmp.jor.br

v. 10, n. 1, January - Ferbuary 2019

ISSN: 2236-269X

DOI: 10.14807/ijmp.v10i1.830

improvement model. In Table 5 each step of UIC model is described and showed the recommended tools to apply on every step:

Table 5: Steps and tools in UIC model

\begin{tabular}{|c|c|c|}
\hline Step & Description & $\begin{array}{l}\text { Recommended tools and } \\
\text { actions }\end{array}$ \\
\hline $\begin{array}{l}\text { 1a) Identity Value Steam, } \\
\text { current \& next constraint \& } \\
\text { Performance Metrics }\end{array}$ & \multirow{3}{*}{$\begin{array}{c}\text { At this phase is } \\
\text { characterized the value flow } \\
\text { and the constraint identified. } \\
\text { Waste, defects and variation } \\
\text { are defined, measured and } \\
\text { analysed. }\end{array}$} & $\begin{array}{l}\text { - VSM, Flow \& Inventory } \\
\text { Analysis, Performance } \\
\text { Metrics Analysis }\end{array}$ \\
\hline $\begin{array}{c}\text { 1b) Define, Measure \& } \\
\text { Analyse waste in current } \\
\text { constraint }\end{array}$ & & $\begin{array}{l}\text { - Run Charts, Spaghetti } \\
\text { Diagrams, Time \& Motion } \\
\text { Studies, C \& E Diagram, } \\
\text { Future State VS Map }\end{array}$ \\
\hline $\begin{array}{c}\text { 1c) Define, Measure \& } \\
\text { Analyse } \\
\text { Variation in current constraint }\end{array}$ & & $\begin{array}{l}\text { - Pareto Charts, Run } \\
\text { Charts, C \& E Diagram, } \\
\text { Causal Chains }\end{array}$ \\
\hline $\begin{array}{l}\text { 2a) Plan How } \\
\text { current con }\end{array}$ & \multirow{3}{*}{$\begin{array}{l}\text { Constraint is improved and } \\
\text { stabilized in simultaneous. } \\
\text { The process will became } \\
\text { more trustful, predictable } \\
\text { and consistent. }\end{array}$} & $\begin{array}{l}\text { - Plan How to Exploit } \\
\text { current constraint }\end{array}$ \\
\hline $\begin{array}{l}\text { 2b) Reduce waste and Cycle } \\
\text { Time on current constraint }\end{array}$ & & $\begin{array}{c}\text { - 5S, Processing Time } \\
\text { Reduction, Mfg Cells, } \\
\text { Standardized Work, Visual } \\
\text { Aids }\end{array}$ \\
\hline $\begin{array}{l}\text { 2c) Reduce variation and } \\
\text { defects in the current } \\
\text { constraint }\end{array}$ & & $\begin{array}{l}\text { - Problem Solving } \\
\text { Roadmap, DOE, Paths of } \\
\text { Variation Reduction }\end{array}$ \\
\hline $\begin{array}{l}\text { 3a) Plan How to Subordinate } \\
\text { Non-Constraints to current } \\
\text { constraint }\end{array}$ & \multirow{3}{*}{$\begin{array}{l}\text { The flow of materials and } \\
\text { information is optimized. It's } \\
\text { necessary to solve problems } \\
\text { that affect the consistency of } \\
\text { the flow. }\end{array}$} & $\begin{array}{c}\text { - Plan How to Subordinate } \\
\text { Non-Constraints to current } \\
\text { constraint }\end{array}$ \\
\hline $\begin{array}{l}\text { 3b) Reduce processing Time } \\
\text { and Establish Flow }\end{array}$ & & $\begin{array}{l}\text { - Improve Flow \& Partial } \\
\text { Line Balance (Time \& } \\
\text { Motion Study) }\end{array}$ \\
\hline $\begin{array}{l}\text { 3c) Implement DBR, constraint } \\
\text { buffer and Pull System }\end{array}$ & & $\begin{array}{l}\text { Optimize Buffer Size and } \\
\text { Time \& Non-Constraint } \\
\text { Pull Systems }\end{array}$ \\
\hline $\begin{array}{l}\text { 4a) Plan How to elevate } \\
\text { constraint and define } \\
\text { protective controls }\end{array}$ & \multirow{3}{*}{$\begin{array}{l}\text { At this phase is necessary to } \\
\text { insurance that all changes } \\
\text { and improvements are to } \\
\text { stay in the future and cannot } \\
\text { be wasted. }\end{array}$} & $\begin{array}{l}\text { - Plan How to elevate } \\
\text { constraint and define } \\
\text { protective controls }\end{array}$ \\
\hline $\begin{array}{l}\text { 4b) Elevate the constraint if } \\
\text { required }\end{array}$ & & $\begin{array}{c}\text { - Perform Capacity } \\
\text { Analysis and Cost/Benefit } \\
\text { Analysis }\end{array}$ \\
\hline $\begin{array}{l}\text { 4c) Implement protective } \\
\text { controls to sustain the gains }\end{array}$ & & $\begin{array}{l}\text { - Perform Process Audit \& } \\
\text { Policy Analysis }\end{array}$ \\
\hline
\end{tabular}

Source: adapted from Sproull (2009)

\section{A TLS MODEL TO PRODUCTION SYSTEM IMPROVEMENT}

According to Sproull, the key of success of integrated TLS models it's in the first place to identify the constraint, and then to decide how to exploit the constraint applying the appropriate Lean and Six-Sigma tools and in the third place 
INDEPENDENT JOURNAL OF MANAGEMENT \& PRODUCTION (IJM\&P)

http://www.ijmp.jor.br

v. 10, n. 1, January - Ferbuary 2019

ISSN: 2236-269X

DOI: 10.14807/ijmp.v10i1.830

subordinating all the rest to the constraint and finally, if necessary, breaking the constraint with monetary investment (SPROULL, 2009) .

The proposed new model ment to grant flexibility in a way that could be applied on any productive system even if it was previously improved by a Lean and/or Six-Sigma project before (SILVA, 2015). A simplified sketch of the proposed TLS model is presented in Figure 7

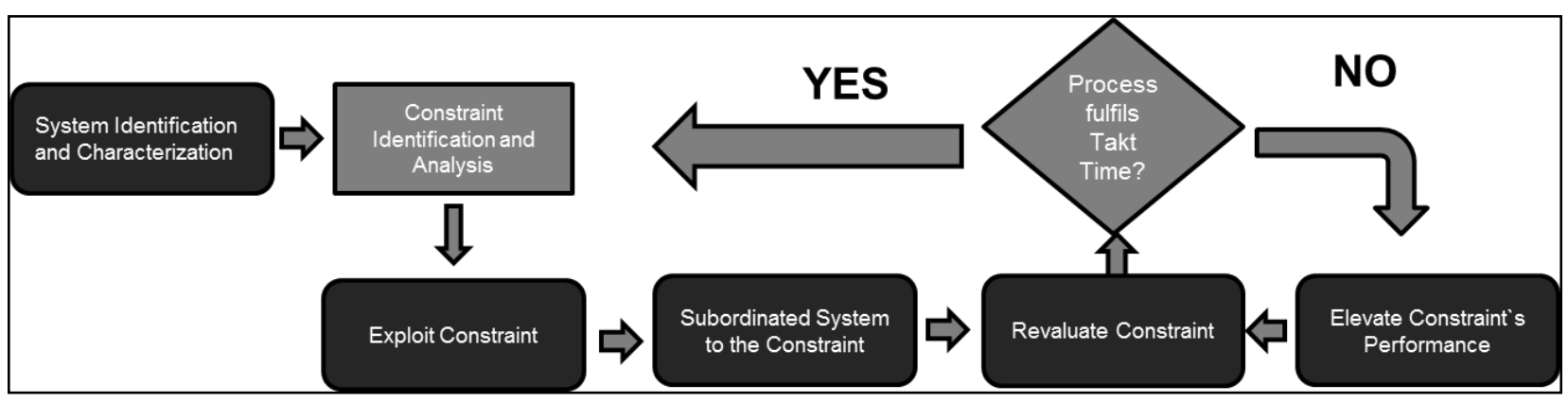

Figure 7: Simplified Sketch of TLS proposed model

The model presented in the previous figure can suit as roadmap for the implementation of a continuous improvement project. As each project is different when applying the model, it could be necessary to adapt it depending on the output obtained at the end of each step. The model is flexible and there are points where it's required to take decisions and in some systems, it's possible to skip any step if the tools and logics indicated to implement at that phase are already correctly applied.

Next, on this chapter every step of the proposed TLS model is described in detail with the tools and logics recommended to be used at each step.

\subsection{Analyse System and Identify Constraint - Figure 8}

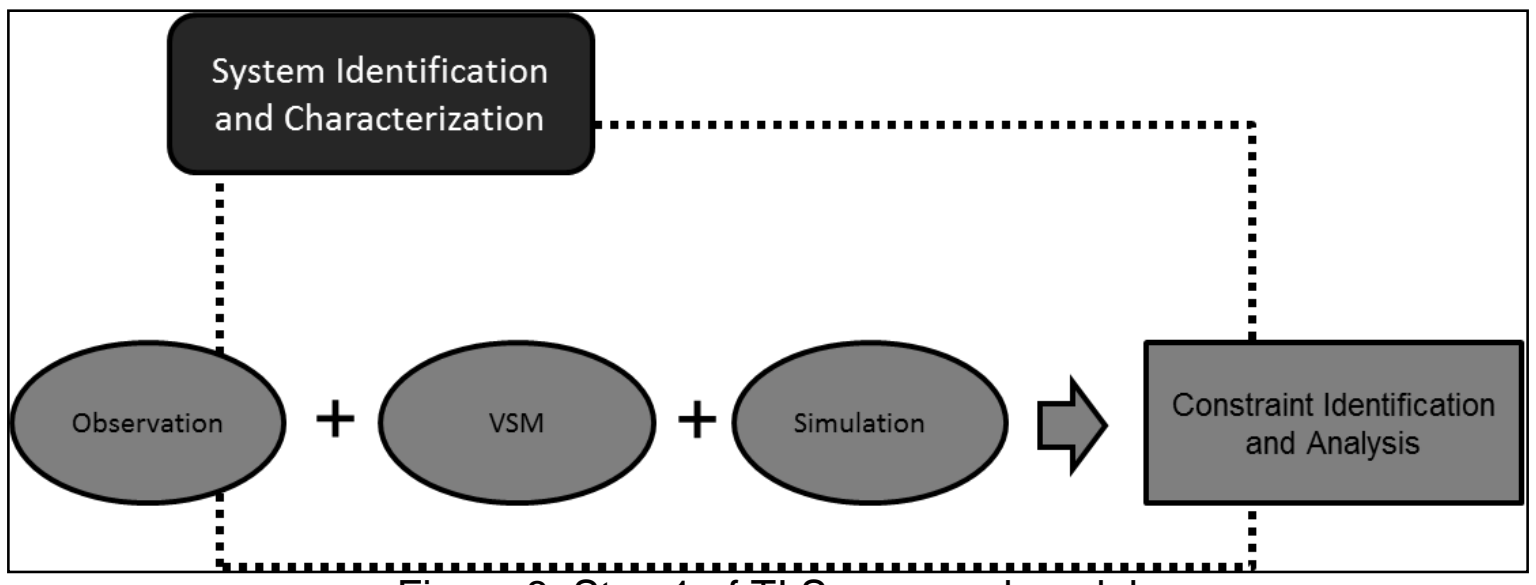

Figure 8: Step 1 of TLS proposed model 
After identifying the system and its frontiers, the leader responsible for the implementation of TLS project should characterize it thoroughly in a way to obtain full knowledge about its operation. To get to Constraint's identification it's recommended to:

- Design process diagram and obtained all information necessary to build a VSM in order to understand the value of the existing flow in current system and determine the existing Lead Time.

- Promote a real system simulation, if possible, placing it at the maximum capacity to evaluate the evolution of inventory before each step of the process. This assumes that it's operating only during normal working hours and every process pushes WIP to the next process of the system and operators work at a normal rhythm during all the simulation.

When comparing the results of the two previous tools it is identified and validate with reliability system's constraints. All the efforts and improvement focus must stay, at this moment in the Constraint. This process must be analysed with more detail and a team must be mobilized to decide the approach and how to exploit the constraint.

\section{2. $\quad$ Exploit Constraint - Figure 9}

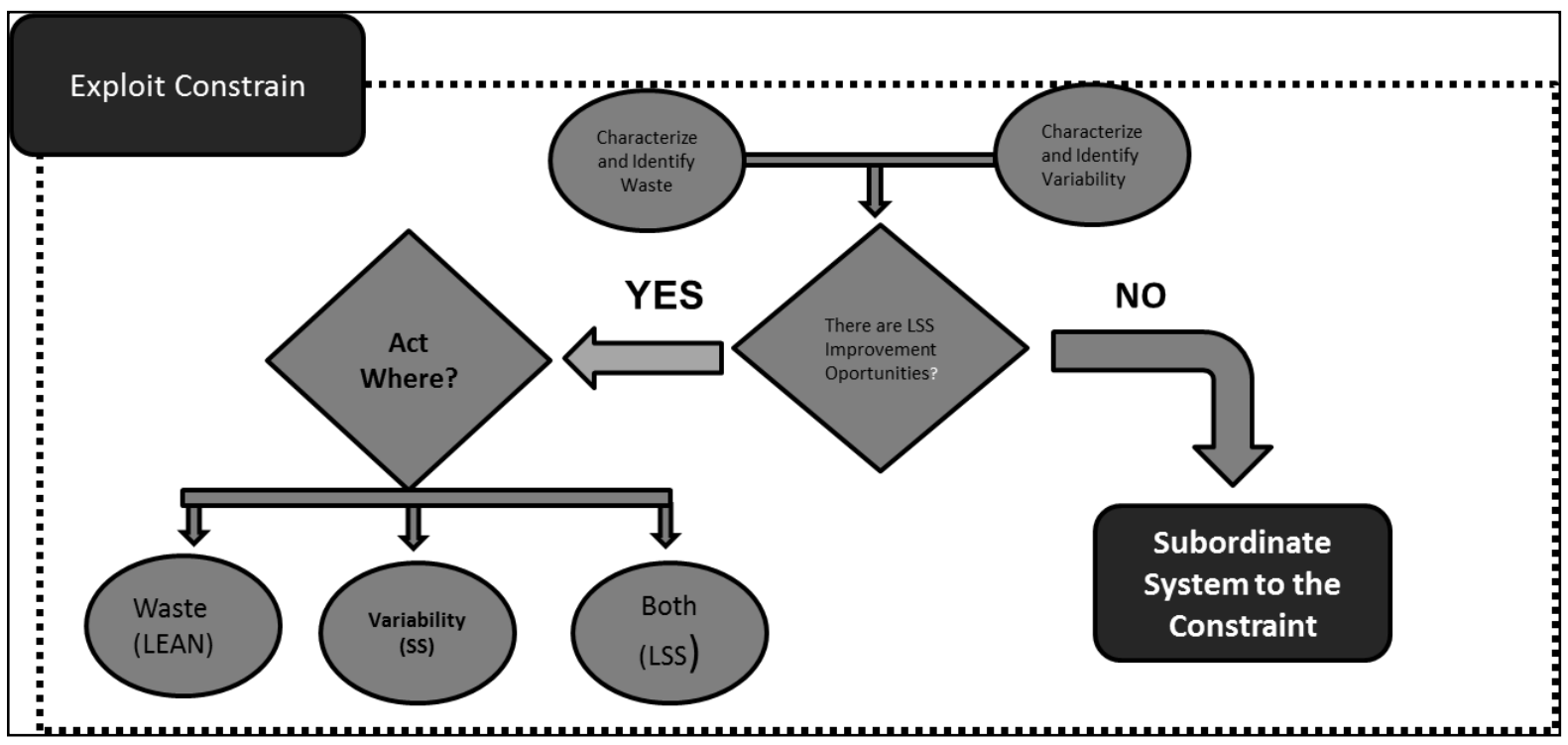

Figure 9: Step 2 of TLS proposed model

On this step of the proposed TLS model it is necessary to identify and measure Waste (Muda). Some possibly logical tools to which can be resorted are:

- Study motion with Spaghetti Diagram; 
- Go to Gemba to detect possible opportunities in $5 \mathrm{~S}$ and if visual aid is appropriate;

- Check the needs for Standardized work or losses in tool exchanges (changeovers);

- Check if performance metrics and OEE are being correctly measured;

- Compare VSM current State with pretended Future State and plan and implement continuous improving Kaizen events;

Simultaneously to the identification of waste it's necessary to characterize and identify variability in the constraint. The recommended logics and tools to apply are:

- Apply Voice of Costumer, Run Charts, Check sheets and MSA;

- Create Pareto Charts to identify main causes of variability;

- Study causes and effects with Ishikawa Diagram and 5 Whys;

- Make gage R\&R studies;

- Study potential impact of defects reduction.

Now it's possibly to answer the question 2a: "If there is LSS improvement opportunities?" In case of the system being already too exploited, the solution is to go to next step of the model and subordinate the others processes to the constraint. Otherwise depending on the opportunities found before, it's chosen where to act and that corresponds to question $2 \mathrm{~b}$. In case of finding improvement opportunities that can help reducing waste, some recommended tools are:

- Apply 5S and improve section's visual aid;

- Implement SMED;

- Allocate machines, organize work and reduce unnecessary motions;

- Standardize and normalize changes;

- Implement continuous flow and reduce Lead Time;

- Create needed indicators.

For the variability opportunities found, the Six-Sigma tools and logics recommend to apply are:

- Making opportunity flow diagram and Matrix FMEA;

- Implementing Statistical Process Control resourcing to DOE, Control Charts and

- Process Capacity;

- Studying equipment reliability; 
- Giving formation to operator about maintenance, stoppages and variability and defects reduction;

- Reducing DPMO (Defects per Million Opportunities) until it gets close to level 6 of Sigma.

\subsection{Subordinate System to the Constraint - Figure $\mathbf{1 0}$}

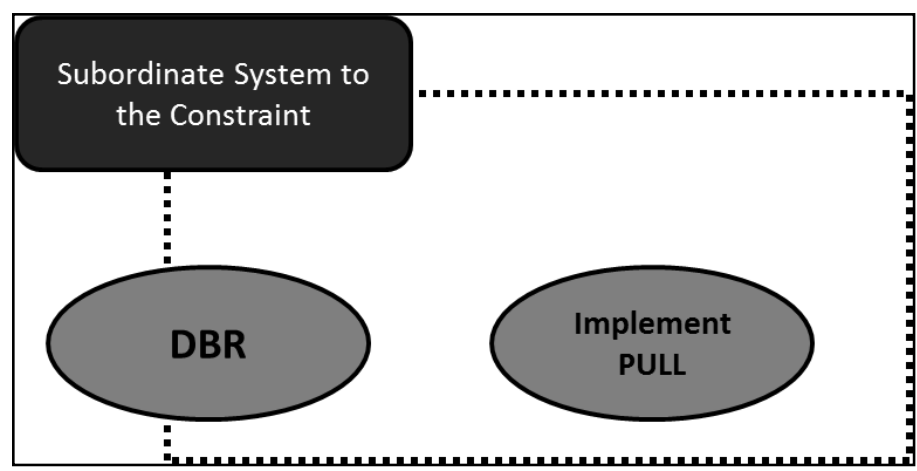

Figure 10: Step 3 of TLS proposed model

After implementing Lean and/or Six-Sigma improvements the next step is to check if DBR and Pull are already being correctly applied in the system. If the correct tools are in use, than it's necessary to make the whole system using them properly. The Kanban and Buffer should get optimized before constraint in a way that the bottleneck stays always fed with materials to avoid unnecessary stoppages.

\subsection{Revaluate Constraint and Elevate Constraint's Performance - Figure 11}

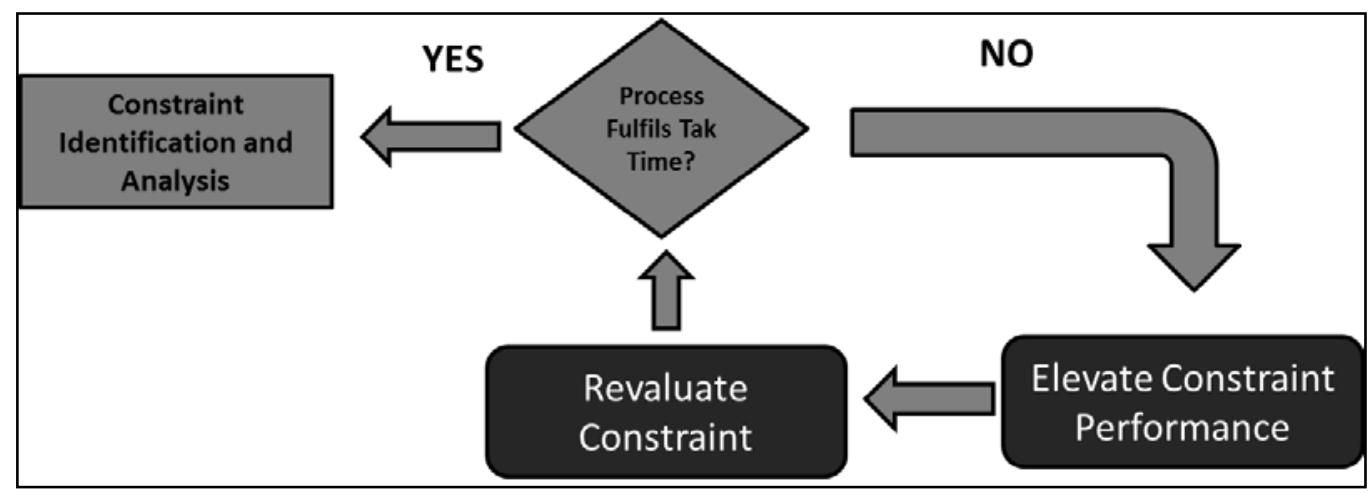

Figure 11: Step 4 \& 5 of TLS proposed model

At this step, the Constraint needs to be revaluated. In case the process now fulfils Takt Time, this means that its capacity is superior to the current demand rate than it closes the first continuous improvement cycle.

In this transaction between cycles, it's important to keep the improvement active and critical attitude to avoid deterioration of the good practices achieved. 
To identify new constraint of the second improvement cycle it should be made an actualization of the VSM or another simulation with the new parameters of the current situation. Internal audits, with focus on the control of the improvements applied are recommended, to avoid the process to become a constraint again.

On the other hand, if the constraint still can't keep up with Takt Time it is required to go to step 5 of the model. To elevate constraint's performance at this moment, monetary investment can became the only solution. These investments can be done through:

- Buying new machines and equipment;

- Hiring more operators;

- Changing plant layout;

- Solving external factors to the system;

- Searching for better technology and innovation.

The entire model is shown in figure 12 :

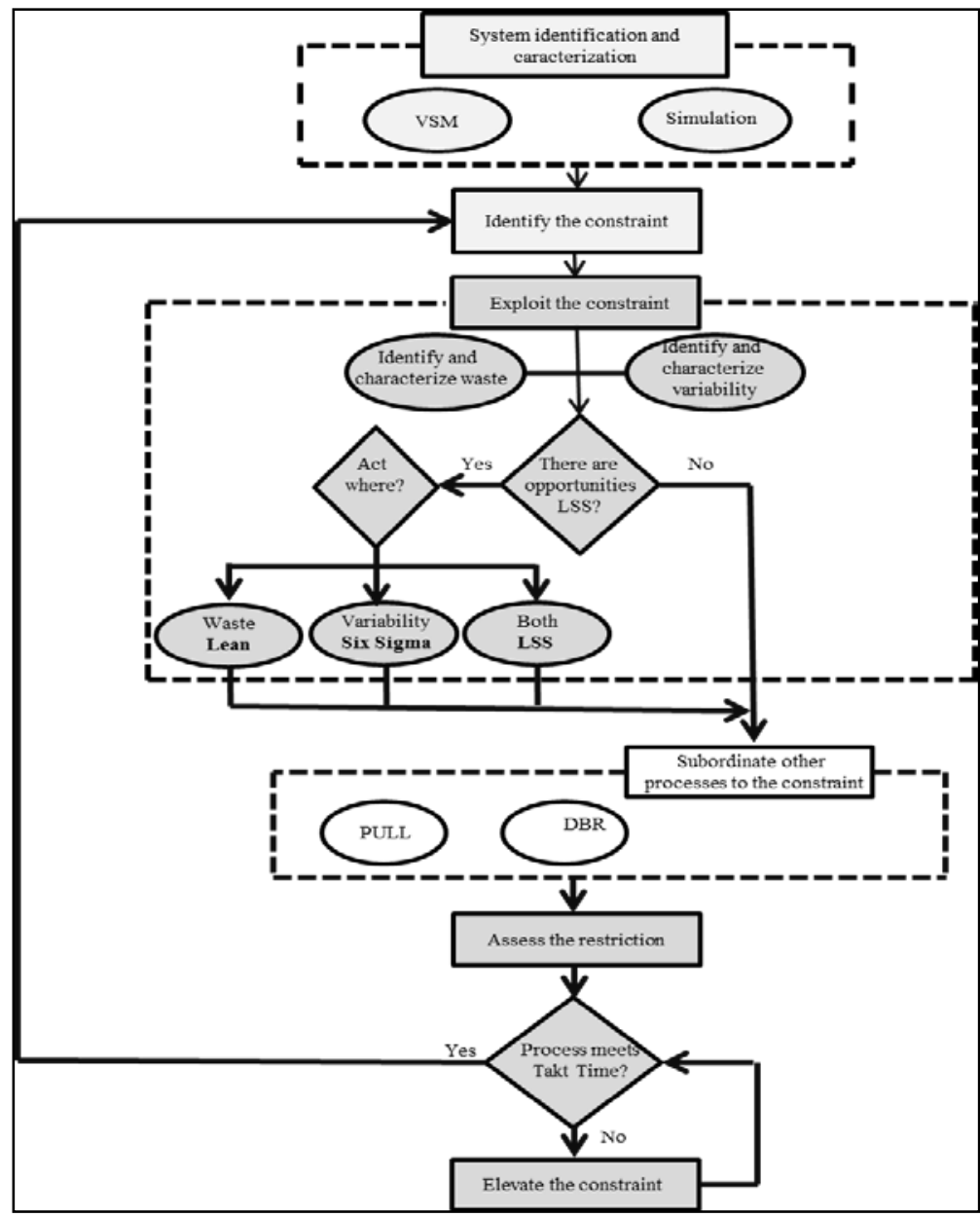

Figure 12: TLS model to Production System Improvement 
INDEPENDENT JOURNAL OF MANAGEMENT \& PRODUCTION (IJM\&P)

http://www.ijmp.jor.br

v. 10, n. 1, January - Ferbuary 2019

ISSN: 2236-269X

DOI: 10.14807/ijmp.v10i1.830

\section{RESULTS OF TESTING THE TLS PROPOSED MODEL ON A LEAN PRODUCTIVE SYSTEM}

The proposed TLS model was tested in a Lean productive system of an important Portuguese manufacturer where a three year old Lean Program was implemented.

The organization wanted to maintain a Lean as a continuous improvement methodology, but it showed total openness to experiment other continuous improvement methodologies or integration of others like a TLS.

In the Table 6 it's described which were the tools and logics used in each one of the phases of the model and what the expected impact in the system under study.

Table 6: Tools, Logics and impact expected impact in each one of the phases of the proposed model

\begin{tabular}{|c|c|c|}
\hline Step & Tools and Logics & Expected Impact \\
\hline $\begin{array}{l}\text { 1) Characterize system and } \\
\text { identify constraint }\end{array}$ & $\begin{array}{c}\text { Process diagram } \\
\text { Nominal capacity of every Process } \\
\text { Lead Time calculation } \\
\text { VSM and Current State } \\
\text { Real system simulation }\end{array}$ & $\begin{array}{l}\text { Incial characterization of the system } \\
\text { Add value } \\
\text { Determinations of the points where } \\
\text { are inventory accumulation } \\
\text { Constraint identification }\end{array}$ \\
\hline $\begin{array}{l}\text { 2a) Identify opportunities for } \\
\text { improvement LSS }\end{array}$ & $\begin{array}{c}\text { Observe GEMBA } \\
\text { Spaghetti Diagram Detection of } 5 S \\
\text { opportunities and visual management } \\
\text { failures } \\
\text { Needs of Standard Work } \\
\text { Comparison of Current state vs Future } \\
\text { State } \\
\text { Pareto Diagram of defects before and } \\
\text { after constraint } \\
\text { Is hikawa Diagram }\end{array}$ & $\begin{array}{l}\text { Characterization of MUDA and } \\
\text { variability } \\
\text { Verification the existance of } \\
\text { opportunities LSS }\end{array}$ \\
\hline $\begin{array}{l}\text { 2b) - Exploit Constrain - } \\
\text { Apply LSS }\end{array}$ & $\begin{array}{c}\text { OEE and other KPI's } \\
\text { Improvement in } 5 \text { S and Visual } \\
\text { Mangement } \\
\text { Improvement of Mizumashi cycle } \\
\text { Work organization } \\
\text { Standard Work } \\
\text { SPC } \\
\text { DPMO } \\
\text { Mesurement of Dowtime }\end{array}$ & $\begin{array}{c}\text { Reduction of waste } \\
\text { Redution/elimination of variability }\end{array}$ \\
\hline $\begin{array}{l}\text { 3) Subordinate the System to } \\
\text { the Constrain }\end{array}$ & Drum - Buffer - Rope & $\begin{array}{l}\text { System submitted to the rhythm of } \\
\text { Constraint }\end{array}$ \\
\hline 4 )Revaluate Constraint & $\begin{array}{c}\text { Compare actual system performende } \\
\text { with Takt Time } \\
\text { Update VSM }\end{array}$ & $\begin{array}{c}\text { Process isn `t Constraint of the } \\
\text { system } \\
\text { New Constrain }\end{array}$ \\
\hline 5) Elevate Constraint & $\begin{array}{l}\text { Bu dget necess ary to elevate Constraint } \\
\text { (inthis case isn't necess ary) }\end{array}$ & $\begin{array}{l}\text { Investement in the process to } \\
\text { eliminate de Constraint }\end{array}$ \\
\hline
\end{tabular}

In the first step of the model two different techniques have been used to identify the constraint: 
INDEPENDENT JOURNAL OF MANAGEMENT \& PRODUCTION (IJM\&P)

http://www.ijmp.jor.br

v. 10, n. 1, January - Ferbuary 2019

ISSN: 2236-269X

DOI: 10.14807/ijmp.v10i1.830

- Real system simulation - Figure 13

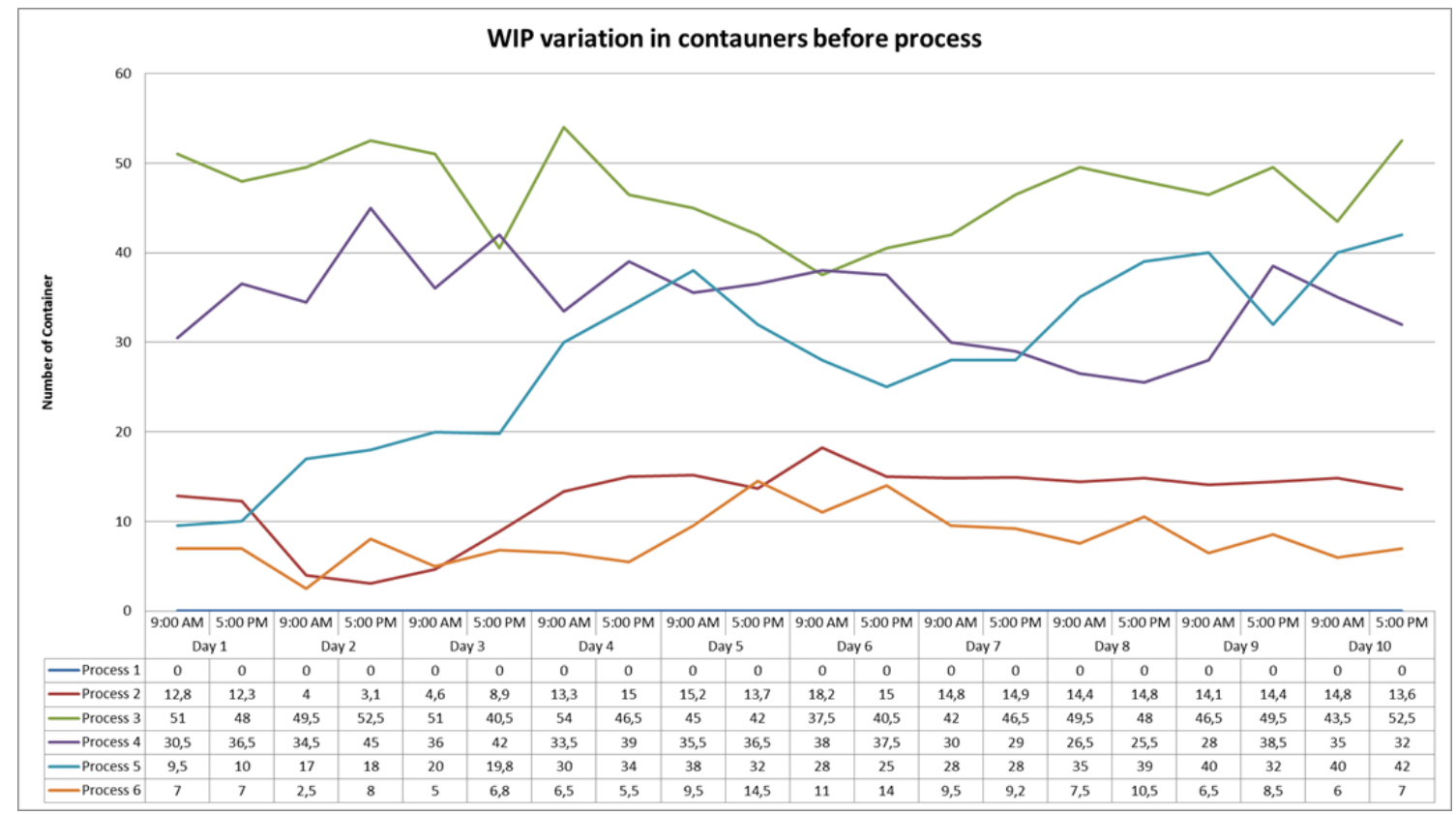

Figure 13: WIP variation before process

Table 7: Trend line equation of variation of WIP before process

\begin{tabular}{c|cc} 
WIP before: & Trend line equation & Slope \\
\hline Process 1 & $-\overline{0}$ & \\
Process 2 & $y=0,399 x+8,408$ & 0,399 \\
Process 3 & $y=-0,129 x+48,150$ & $-0,129$ \\
Process 4 & $y=-0,362 x+38,255$ & $-0,362$ \\
Process 5 & $y=1,426 x+13,29$ & 1,426 \\
Process 6 & $y=0,127 x+6,769$ & 0,127
\end{tabular}

After analysing the Table 7 it is possible to conclude that the constraint is located in process 5, because it's in this stage that the trend line of WIP has greater slope.

- VSM - Cycle Time

Table 8: System Cycles time

\begin{tabular}{|c|cccccc}
\hline & Process 1 & Process 2 & Process 3 & Process 4 & Process 5 & Process 6 \\
\hline $\begin{array}{c}\text { Cycle Time } \\
\text { (s/piece) }\end{array}$ & 31,19 & 33,67 & 33,89 & 32,53 & 39,09 & 35,08
\end{tabular}

In process 5 the Cycle Time is longer - Table 8 , so it's possible to conclude that the constraint is located at this step of the system.

The conclusions obtained about system's constraints were equal in both methods and it was possibly to define with reliability the existing first improvement cycle's constraint. That process was analysed with more detail and a team was assigned with the task of focusing on process improvement. 
INDEPENDENT JOURNAL OF MANAGEMENT \& PRODUCTION (IJM\&P)

http://www.ijmp.jor.br

v. 10, n. 1, January - Ferbuary 2019

ISSN: 2236-269X

DOI: 10.14807/ijmp.v10i1.830

After the constraint was exploited corresponding to the second step of the proposed TLS model and several Lean Six-Sigma (LSS) opportunities were identified. On those identified and characterized opportunities for waste and variability reduction it was applied the most appropriate Lean and Six-Sigma tools to solve them - Table 7.

After improving the constraint with LSS, it was verified if Pull logic was implemented in the system and if DBR was applied properly before the constraint. There was no need to make any changes in the study case system because Pull and DBR were already well applied and the existing Kanban and buffers were well optimized.

At this moment it was possibly to revaluate constraint found in the first improvement cycle. Table 9 compares the values encountered for Cycle Time in seconds to produce one piece on every process at the initial conditions that the system was found (October 2014) with the values obtained at the moment of constraint's revaluation (April 2015):

Table 9: Comparison of system's Cycle Time (seconds to produce one piece)

\begin{tabular}{|c|c|c|c|c|c|c|}
\hline & Process 1 & Process 2 & Process 3 & Process 4 & Constraint & Process 6 \\
\hline $\begin{array}{c}\text { Initial Cycle Time } \\
\text { (October 2014) }\end{array}$ & 31,19 & 33,67 & 33,89 & 32,53 & 39,09 & 35,08 \\
\hline $\begin{array}{c}\text { Cycle Time (April } \\
\text { 2015) }\end{array}$ & 29,80 & 29,84 & 29,66 & 31,72 & 26,48 & 29,09 \\
\hline
\end{tabular}

From the table above, it is possible to conclude that the constraint became one of the most efficient processes in the system and it is also possible to notice that all the other processes in the system improved due to the leverage created by the reduction of constraint's Cycle Time avoiding delays and waiting for materials provision.

In the initial conditions that the study case was found the Cycle Time calculated for the bottleneck was 39,09 seconds to produce one piece and when revaluated after the LSS improvements it was only required 26,48 seconds/ piece. This corresponds to a reduction of over 32\% in Cycle Time on the constraint just by the application of the suitable LSS tools.

Calculated Takt Time corresponding to the rate of costumers demand was establish at 33,88 seconds/ piece which means that the constraint fulfils successfully the Takt Time demanded by system's clients. 
INDEPENDENT JOURNAL OF MANAGEMENT \& PRODUCTION (IJM\&P)

http://www.ijmp.jor.br

V. 10, n. 1, January - Ferbuary 2019

ISSN: 2236-269X

DOI: 10.14807/ijmp.v10i1.830

Table 10 shows some performance indicators results in terms of Productivity and Quality in the two months when LSS improvements occurred (January and February 2015) and on the two following months after the first cycle improvements (March and April 2015) on constraint:

Table 10: Performance indicators on constraint

\begin{tabular}{|c|c|c|c|}
\hline \multicolumn{2}{|l|}{ Productivity } & \multicolumn{2}{|c|}{ Quality } \\
\hline $\begin{array}{l}\text { Average of daily processed } \\
\text { quantity (pieces/ day) }\end{array}$ & $\begin{array}{c}\text { OEE average } \\
(\%)\end{array}$ & $\begin{array}{c}\text { Defects average } \\
\text { (\%) }\end{array}$ & $\begin{array}{l}\text { Stoppage time due to } \\
\text { malfunctions (hours) }\end{array}$ \\
\hline \multicolumn{4}{|c|}{ January 2015} \\
\hline 2.894 & $62,17 \%$ & $9,7 \%$ & $198 \mathrm{~h}$ \\
\hline \multicolumn{4}{|c|}{ February 2015} \\
\hline 3.130 & $68,13 \%$ & $10,8 \%$ & $91 \mathrm{~h} 30$ \\
\hline \multicolumn{4}{|c|}{ March 2015} \\
\hline 3.217 & $76,88 \%$ & $9,2 \%$ & $29 \mathrm{~h} 30$ \\
\hline \multicolumn{4}{|c|}{ April 2015} \\
\hline 3.175 & $77,07 \%$ & $8,5 \%$ & 14h15 \\
\hline
\end{tabular}

With this obtained results it was possible to close the first improvement cycle of the proposed TLS model. It was not necessary to elevate constraint's performance with financial resourcing corresponding to the fifth step of the model.

In the transition between cycles the creation of a continuous improvement attitude was defined with the Industrial Manager. For that reason the former constraint was kept under control, a meeting between the improvement team about constraint situation kept being realized once a week and it was implemented internal audits in the whole system, with special attention on Capacity-Constrained resources found at the first improvement cycle.

So a second improvement cycle was needed, starting by the updating of the previous VSM with the new data collected. A new improvement cycle begins.

\section{MAIN CONCLUSIONS}

Reviewing of continuous improvement systems it's possible to verify that from the existing systems found at state of art, the reported to bring better results for managers are the ones that integrate the methodologies Theory of Constraints, Lean production and Six-Sigma in a single improvement project.

This paper proposed a TLS model that shows flexibility to be applied in any system. To test the proposed hypothesis it was decided to implement it in an 
important Portuguese manufacturer Lean productive system. The application of a TLS model demonstrate to be not more difficult than the implementation of a Lean or Six-Sigma project alone, because the focus of a TLS project only need to stay on constraint's sector instead of being on the whole system.

It's possible to observe results, even in the first improvement cycle which means that is highly recommend apply TLS projects for short-term results . The constraint found went from being the most inefficient process to become one of the most efficient and also all the others processes benefit from the improvements corresponding in a general reduction of Cycle Time.

There is still a need to validate the proposed model with further discussion and in new real systems to make the implementation. Continuous improvement projects should be taken care with a pro-active attitude and need to be maintained with protective measures to avoid a deterioration of the good results obtained.

\section{REFERENCES}

AGI (2009) Combining Lean, Six Sigma, and the Theory of Constraints to Achieve Breakthrough Performance, White Papper, Goldratt Institute, Disponível em $<$ www.goldratt.com>. Acesso em 15 de Maiol de 2017.

ANTONY, J.; BANUELAS, R. (2002) A strategy for survival, Manufacturing Engineer, v. 80, p.119-121.

COX, J.; SCHLEIER, J. (2010) Theory of Constraints: Handbook, McGraw-Hill, New York.

DAVIES, J.; MABIN, V. (2009) Theory of Constraints, Decision Line, v. 40, n. 2, p. 9-12

GOLDRATT, E.; COX, J. (2004) The goal: A process of ongoing improvement, Third Revised Edition. The north riverpress, Great Barrington, Massachusett.

JACOBS, R.; CHASE, B.; AQUILANO, J. (2009) Operations and Supply Management, McGraw-Hill International Edition, New York.

KHANDEKAR, A.; SULAKHE, V. (2014) Six Sigma - The Revival of TQM. International Journal of Mechanical Engineering and Robotics Research, v. 3, p. 50-58.

LUCAS, D.; TENERA, A. (2014) Input Analysis in Simulation: A Case Study Based on the Variability in Manufacturing Lines, Advances in Intelligent Systems and Computing, v. 280, p. 465-477.

MOURA, E. (2010) The Need to Integrate TOC, Lean, Six Sigma and Management by Processes, proceedings of Theory of Constraints International Certification Organization Conference, TOCICO 
OKIMURA, L.; SOUZA, F. (2012) Análise dos Modelos de Integração das Abordagens Teoria das Restrições, Produção Enxuta e Seis Sigma: Um Estudo Teórico. VIII Brazilian Congress of Excellence in Management.

PACHECO, D. (2014) Teoria das Restrições, Lean Manufacturing e Seis Sigma: limites e possibilidades de integração, Production, v. 24, n. 4, p. 940-956.

PEREIRA, Z.; REQUEIJO, J. (2012) Qualidade: Planeamento e Controlo Estatístico de Processos, FFCT-Fundação da Faculdade de Ciências e Tecnologias da Universidade Nova de Lisboa, Lisbon.

PIRASTEH, R.; FARAH, K. (2006) Continuous Improvement Trio: The Top Elements of TOC, Lean, and Six Sigma Make Beautiful Music Together. APICS Magazine, v. 16, n. 5, p. 31-33.

PIRASTEH, R.; FOX, R. (2010) Profitability With no Boundaries: Focus, reduce waste, contain variability, optimize TOC, Lean, Six Sigma Results. ASQ Quality Press, Wisconsin.

PRETORIUS, P. (2014) Introducing in-between decision points to TOC's five focusing steps, International Journal of Production Research, v. 52, n. 2, p. 496506.

SILVA, L. D. (2015) Ensaio exploratório de um modelo TLS num Sistema Produtivo Lean: Caso Equipar. Tese de Mestrado em Engenharia e Gestão Industrial, Universidade Nova de Lisboa - Faculdade de Ciências e Tecnologia, Lisboa

SPROULL, B. (2009) The Ultimate Improvement Cycle: Maximizing Profits through the Integration of Lean, Six Sigma, and the Theory of Constraints, CRC Press, Taylor \& Francis Group, Boca Raton, Florida.

SPROULL, B. (2010) The Ultimate Improvement Cycle: Maximizing Profits through the integration of Lean, Six Sigma and Theory of Constraints, CRC Press, New York, NY.

STAMM, M. L.; NEITZERT, T.; SINGH, D. (2009) TQM, TPM, Lean and Six Sigma Evolution of Manufacturing methodologies under the paradigm from shift Taylorism/Fordism to Toyotism?, proceedings of 16th International Annual EurOMA Conference 2009, Gothenburg, Sweden.

TENERA, A. (2006) Contribuição para a melhoria da gestão da incerteza na duração dos projectos através da teoria das restrições. $\mathrm{PhD}$ Thesis. Universidade Nova de Lisboa - Faculdade de Ciências e Tecnologia, Lisbon.

TENNANT, G. (2001) SIX SIGMA: SPC and TQM in Manufacturing and Services. Gower Publishing, Ltd New York. pp. 6.

WOMACK, J.; JONES, D. (1996) Beyond Toyota: How to Root Out Waste and Pursue Perfection, Harvard Business Review, v. 74, n. 5, p.140-158. 